\title{
Coronal microleakage of restorations with or without cervical barrier in root-filled teeth
}

\section{Microinfiltração coronária de restaurações com ou sem barreira cervical em dentes endodonticamente tratados}

\begin{abstract}
Purpose: To evaluate the ability sealing of glass ionomer and composite resin with or without 1 -mm thickness of Coltosol on the root-canal filling material.

Methods: Root-canal treatment was completed on 50 -extracted human mandibular unirradicular. The teeth were divided into six groups: G1, positive control; G2, negative control; G3, glass ionomer (Vidrion R); G4, Coltosol + Vidrion R; G5, composite resin; and, G6, Coltosol + composite resin. For $G 1$ and $G 2$ five teeth each were used and for the other groups, ten teeth each. The teeth were thermocycled and evaluated for microleakage using methylene blue dye. Specimens were sectioned and measurements made to the maximum point of dye penetration. The mean dye penetration (\%) for each group was compared by ANOVA and Tukey's test for post-hoc comparisons $(\alpha=0.05)$.

Results: The means and standard deviations of microleakage were: $G 1,96.56$ ( \pm 2.31$)$; G2, 0.00 ( \pm 0.00$) ; G 3,68.76( \pm 24.63) ; G 4,24.42$ ( \pm 8.33$) ; G 5,20.06$ ( \pm 9.35$) ;$ and, G6, $12.86( \pm 6.08)$

Conclusion: It was concluded that none of the materials were able to prevent microleakage. Composite resin alone or combined with coltosol and glass ionomer associated with coltosol resulted in less microleakage than the glass ionomer used alone.
\end{abstract}

Key words: Coronal microleakage; adhesive system; composite resin; temporary fillings

\section{Resumo}

Objetivos: Avaliar a capacidade de selamento do ionomero de vidro e resina composta, com ou sem $1 \mathrm{~mm}$ de coltosol, sobre o material obturador endodôntico.

Métodos: $O$ tratamento endodôntico foi realizado em 50 dentes humanos mandibulares unirradiculares. Os dentes foram divididos em 6 grupos: G1, controle positivo; G2, controle negativo; G3, ionômero de vidro (Vidrion R); G4, Coltosol + Vidrion R; G5, resina composta; e, G6, Coltosol + resina composta. Os dentes foram submetidos a termociclagem e a avaliação da microinfiltração usando azul de metileno. Os especimes foram seccionados e a quantidade maxima de penetração de corante avaliado. As medias e desvios-padrão de penetração do corante (em \%) para cada grupo foram analisadas pelo teste ANOVA e pelo teste de multiplas comparações de Tukey's $(\alpha=0.05)$.

Resultados: As medias e desvios-padrão de midroinfiltração foram: $G 1: 96,56( \pm 2,31)$; G2: $0,00( \pm 0,00) ; G 3: 68,76( \pm 24,63) ; G 4: 24,42( \pm 8,33) ; G 5: 20,06( \pm 9,35)$; and, G6: $12,86( \pm 6,08)$.

Conclusão: Pode-se concluir que nenhum material obturador preveniu completamente a microinfiltração. Resina composta utilizada isoladamente ou associada ao coltosol e o ionômero de vidro associado ao coltosol apresentaram menor microinfiltração do que o ionomero de vidro utilizado sozinho.

Palavras-chave: Microinfiltração coronária; sistema adesivo; resina composta; restauradores temporários

\author{
Daniela Damman a \\ Renata Grazziotin-Soares a \\ Ana Paula Farina a \\ Doglas Cecchin a
}

a Department of Restorative Dentistry, School of Dentistry of Passo Fundo, University of Passo Fundo (UPF), Passo Fundo, RS, Brazil

\author{
Correspondence: \\ Doglas Cecchin \\ Universidade de Passo Fundo - Campus I - Faculdade \\ de Odontologia \\ Bairro São José, 285 \\ Passo Fundo, RS - Brazil \\ 99052-900 \\ E-mail:dgscecchin@yahoo.com.br \\ Received: January 31, 2012 \\ Accepted: April 17, 2012 \\ Conflict of Interests: The authors state that there \\ are no financial and personal conflicts of interest that \\ could have inappropriately influenced their work. \\ Copyright: (C) 2012 Damman et al.; licensee \\ EDIPUCRS. This is an Open Access article distributed \\ under the terms of the Creative Commons Attribution- \\ Noncommercial-No Derivative Works 3.0 Unported \\ License.
}




\section{Introduction}

The sealing in the access cavity during endodontic treatment is important in order to prevent the entrance of saliva and microorganisms into the root-canal system (1). However, studies showed that coronal microleakage can occur around temporary restorations (2). If the coronal restoration becomes defective or is lost, the coronal leakage can compromise the success of root canal therapy $(3,4)$. Ray and Trope (5) found that the quality of the coronal seal is just as important as the technical quality of the root canal filling for periapical health after root canal therapy.

Coronal microleakage introduces the oral microflora into the root canal system, which can eventually lead to the failure of the endodontic treatment $(3,4)$. To reduce microleakage Roghanizad and Jones (6) suggested placing a coronal seal in the orifice of the root canal immediately after root canal filling. According to Schwartz and Fransman (7) orifice barriers provide a second line of defence against the leakage of bacteria. In an in vivo study, Yamauchi et al. (8) reported a substantial reduction in apical periodontitis when coronal plugs were used.

In relation to the temporary filling coronary studies have shown that Coltosol was significantly better in preventing microleakage other temporary materials $(2,9)$. However, the hygroscopic expansion of Coltosol in a cavity may lead to cusp deflection, infraction development and fracture. Furthermore, in vivo masticatory forces will aggravate this unfavourable condition. Therefore this material is not recommended for temporary filling in root-filled teeth (10).

Adhesive dentistry concepts have increasingly been applied to endodontics to prevent coronal leakage. Some characteristics as ease and speed of placement, sealing efficacy, and high bond strength qualify the ideal restorative material to barrier (11), and the use of dentin bonding agents has been advocated to help provide a better intracoronal seal (12). Therefore the aim of this in vitro study was to evaluate the ability sealing of glass ionomer and composite resin with or without 1-mm thickness of Coltosol on the root-canal filling material.

\section{Methodology}

A total of 50 extracted single-rooted human maxillary anterior teeth were collected under a protocol reviewed and approved by the Ethics Committee for Human Studies, Passo Fundo School of Dentistry, FO-UPF, Brazil. After extraction, teeth were stored in $0.1 \%$ thymol solution for no more than 1 month. Organic debris and calculus were detached with scalers (Hu-Friedy Co; Chicago, IL, USA), and standard access to the pulp chamber was performed and pulp tissue was removed with a barbed broach (Dentsply Maillefer, Ballaigues, Switzerland). A crown-down root canal preparation was performed using Gates-Glidden drills sizes 5, 4, 3 and 2 (Dentsply Maillefer) placed to a length where resistance was met in the coronal and middle thirds of the root canal. This was followed by step-back instrumentation of the apical third to create a size 45 apical stop. Root canals were irrigated during instrumentation using $5 \mathrm{~mL}$ of $2.5 \%$ sodium hypochlorite $(\mathrm{NaOCl})$ (Natufarma Pharmacy; Passo Fundo, RS, Brazil) solution and rinsed with $3 \mathrm{~mL}$ of $17 \%$ ethylenediaminetetraacetic acid (EDTA) (Natufarma Pharmacy) for 5 min to remove the smear layer. Subsequently, a final flush with $10 \mathrm{~mL}$ of distilled water (Natufarma Pharmacy) was performed to wash out the EDTA solution, and root canals were then dried with paper points (Dentsply Maillefer).

The teeth were obturated with gutta-percha and Endo-Fill (Dentsply, Petrópolis, Rio de Janeiro, Brazil) using lateral compaction. After filling the root canal, excess material was removed with a heated instrument Duflex number 2 (SS White; Rio de Janeiro, RJ, Brazil) $1 \mathrm{~mm}$ below root canal orifices. The root canal sealer was removed from the pulp chamber with cotton pellets soaked in $70 \%$ isopropyl alcohol (Natufarma Pharmacy).

Forty teeth were randomly assigned to 4 experimental groups ( $\mathrm{n}=10$ /experimental group), and 10 teeth were randomly assigned to 2 control groups ( $\mathrm{n}=5 /$ control group) as follows: group 1, positive control; group 2, negative control; group 3, glass ionomer chemically cured (Vidrion R, S. S. White Artigos Dentários Ltda., Rio de Janeiro, Brazil); group 4, a 1-mm intracanal barrier of Coltosol (Colten, Langenau, Germany) + Vidrion R; group 5, adhesive system (Adper Scotchbond Multi-Purpose, 3M ESPE, St Paul, MN) associated with composite resin (Z250, 3M ESPE); group 6 , a 1-mm intracanal barrier of Coltosol + adhesive system and composite resin.

The glass ionomer was placed into the pulp chamber by a syringe (Centrix Incorporated, Shelton, USA). Coltosol was placed with a number 1 spatula Duflex (SS White). In the Scotch Bond group, the specimens were etched with $37 \%$ phosphoric acid for $15 \mathrm{~s}$, washed for $10 \mathrm{~s}$ and gently dried with cotton pellets; a thin layer of Primer (3M ESPE) and Bond (3M ESPE) was applied and light cured for $20 \mathrm{~s}$ (Ultraled, Dabi Atlante, Ribeirao Preto, SP, Brazil - power density: $500 \mathrm{~mW} \mathrm{~cm}^{-2}$ ). Composite resin was inserted by incremental technique and light cured for $20 \mathrm{~s}$ each increment.

The teeth received 3 layers of nail polish (Dote Belulla Cosméticos Ltda; Diadema, SP, Brazil), leaving only the area of canal's orifice exposed to provide uniform control of any lateral or accessory canals. The cavit access was restored with resin composite and all surfaces of the negative control group were completely sealed with 3 layers of nail polish. The positive control did not receive material in access cavity.

All teeth were radiographed after the placement of the restorative materials to verify their uniformity and density, and stored for 7 days at $37^{\circ} \mathrm{C}$ and $100 \%$ humidity. The specimens were then subjected to thermocycling between $5^{\circ} \mathrm{C}$ and $55^{\circ} \mathrm{C}$ for 750 cycles. The dwell times in each bath and the time intervals at room temperature between baths were 1 minute. Subsequently, the roots were immersed in 2\% methylene blue dye (Natufarma Pharmacy) for 7 days. Afterwards, they were rinsed in tap water, then dried, and the coatings were completely removed with a scalpel. 
Then they were longitudinally sectioned in a buccolingual direction using a low-speed diamond saw under constant water-cooling. Under a D.F. Vasconcellos microscope (São Paulo, SP, Brazil) at $\times 20$ magnification, methylene blue dye penetration was measured in millimetres at both sides of the specimen as an indicator of coronal microleakage.

The total length of the filling within the root-canal obturation, and the greatest depth of dye penetration along each canal were recorded in millimetres. These measurements were converted to percentages of microleakage related to the total length of the root filling for each root canal. The means and standard deviations of microleakage were calculated, and the data were analysed using ANOVA and Tukey's test for post-hoc comparisons $(\alpha=0.05)$.

\section{Results}

The degree of dye penetration for each group is presented in Table 1. There was no dye penetration for teeth in the negative control group, whereas the positive control group showed dye penetration in all specimens.

Table 1. Mean percentages of microleakage for each group

\begin{tabular}{lc}
\hline \multicolumn{1}{c}{ Material } & Mean microleakage (\%) \\
\hline Positive control & $96.56(2.31)^{a}$ \\
Negative control & $0.00(0.00)^{d}$ \\
Vidrion R & $68.76(24.63)^{b}$ \\
Coltosol + Vidrion R & $24.42(8.33)^{c}$ \\
Composite resin & $20.06(9.35)^{c, d}$ \\
Coltosol + Composite resin & $12.86(6.08)^{c, d}$ \\
\hline
\end{tabular}

${ }^{*}$ Different letters in superscript mean statistically significant differences $(P<0.05)$.
Coltosol + composite resin, composite resin and Coltosol + Vidrion $\mathrm{R}$ sealed significantly better than the other groups $(P<0.05)$. Vidrion $\mathrm{R}$ exhibited the highest microleakage of the experimental groups $(P<0.05)$. All experimental groups showed a statistically significant better seal $(P<0.05)$ than the positive control group, independent of the sealing material used.

\section{Discussion}

Studies have shown that gutta-percha and root canal sealers cannot prevent the passage of saliva and bacteria to the periapical tissues $(4,5,13)$. The results of the current study show that all samples obturated with gutta-percha and sealer without restoration (positive control group) exhibited extensive dye penetration. Therefore, after obturation of the root canal system, the occlusal access cavity should be properly sealed to improve the prognosis of endodontically treated teeth.

Restorative dentistry concepts using adhesive materials have increasingly been applied to endodontics to prevent coronal leakage $(2,11)$, such as use of fibre posts in the restoration of endodontically treated teeth (14), and even for the filling of the root canal (15). The use of these materials is based on the premise that because of the intimate contact with dentine, these materials could remain micromechanically retained, reinforcing tooth structure and preventing root contamination (16). Therefore, the present study focused on the sealing ability of composite resin and glass ionomer materials associated with a thickness of $1.0 \mathrm{~mm}$ of Coltosol in the entrance root canal.
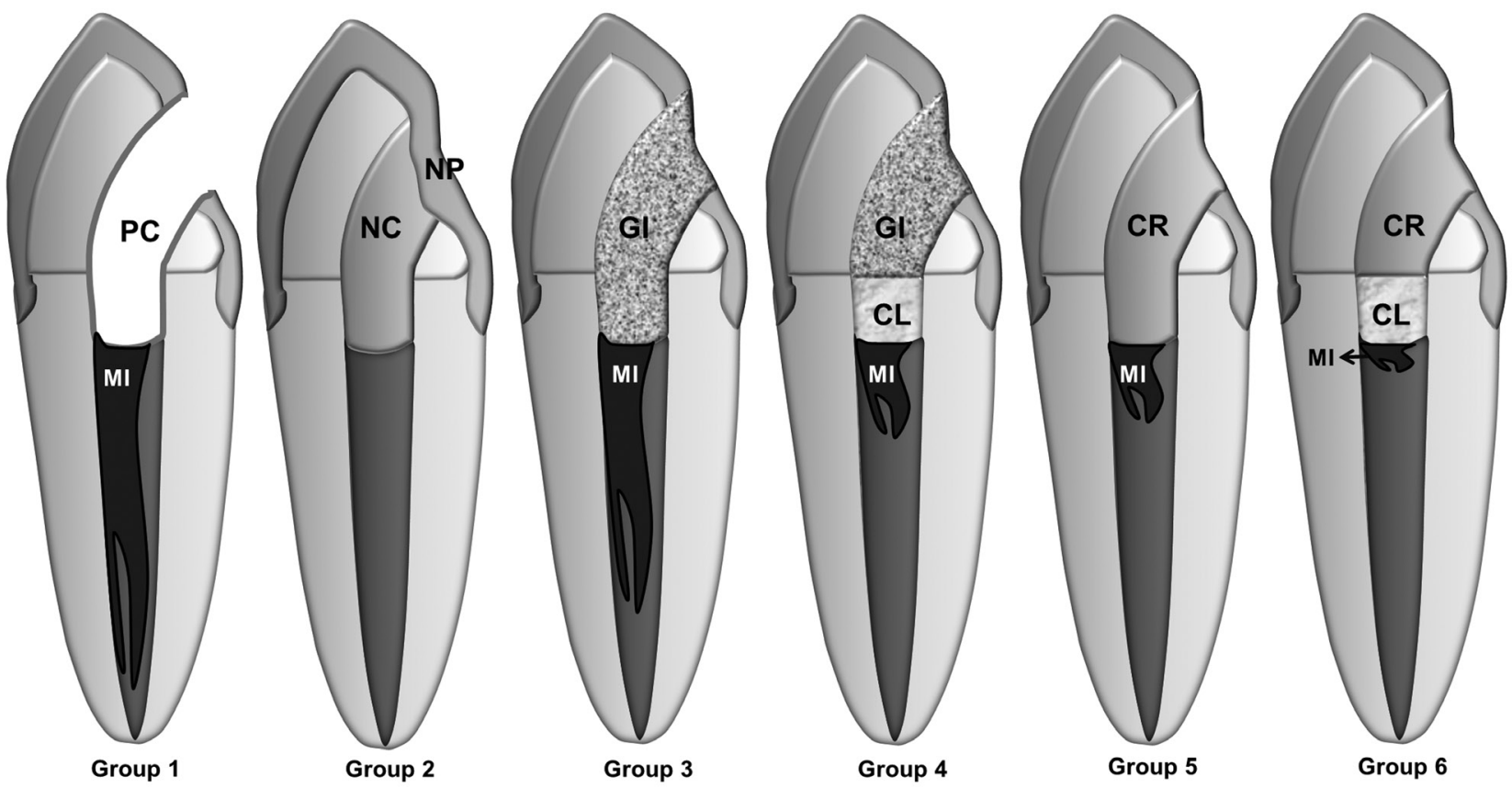

Fig. 1. Schematic illustration of the groups under study. PC: positive control; NC: negative control; NP: nail polish; GI: glass ionomer; CL: coltosol; CR: composit resin. The microleakage locations observed for the groups were as follows in MI (microleakage). 
The results of this in vitro study indicated composite resin and Coltosol + composite resin provided a better seal than glass ionomer, and no difference was found with the negative control. This fact is consistent with some other leakage studies that used adhesives materials for sealing (2, 17-20). Uranga et al. (18) reported that composite resin did not demonstrate any leakage, whereas other experimental materials leaked significantly more. Leonard et al. (19) showed that dentin-bonding agents and resin seal more completely than glass ionomer. Bonded restorations are also recommended by Howdle et al. (20) to decrease leakage.

The possibility of direct restoration of non-vital teeth with resin-based composites has increased owing to the development of adhesive systems (21). These have increased bond strength of composite resins to dentin (22), and produced less microleakage (23). It is assumed that these bondings improve the adhesive capability and bonding strength of resins to the tooth structure by promoting penetration, impregnation, and entanglement of the coupling agents into dentinal substrates where they polymerise in situ and create zones of resin-reinforced dentin layers (24).

The glass ionomer used without Coltosol, whose setting is an acid-base reaction, showed poor sealing ability, as reported by Zaia et al. (2). This is probably due to shrinkage of the material upon setting, resulting in a potential avenue for microleakage and its use may be more technique sensitive (2). Moreover, shrinkage during setting as well as the presence of a smear layer can adversely affect the coronal seal ability of glass ionomer (18). The use of EDTA is recommended to remove the smear layer.

In this study, the use of a 1-mm thickness of Coltosol to seal the pulp chamber after root-canal treatment reduced coronary microleakage. The excellent results obtained by an root canal barrier Coltosol sealing material agree with previous findings $(2,9)$. Coltosol is a pre-manipulated material composed of a single paste free of eugenol, which hardens when exposed to moisture. It is widely used as a temporary restorative material in endodontics and has outstanding sealing properties when compared with other materials for the same purpose $(2,9)$. Coltosol is a hygroscopic cement that expands when it comes into contact with moisture. This expansion provides good adaptation between the restorative material and cavity walls $(2,10,25)$.

According Laustsen et al. (10) the expansion of Coltosol might cause stress in the material as well as the surrounding walls. The stress might partly dissipate because of expansion of material out of the cavity, by a deformation of the walls and by creep or other stress-releasing mechanism. When the stress-induced deformation reaches a certain limit, cracks will develop both in the inner part of the dentine walls, as well as between enamel and dentine, which may lead to fracture of the tooth. Due to the good sealing capability of the Coltosol, it is recommend the use of 1-mm thickness of Coltosol to seal the pulp chamber, and the rest of the cavity must be sealed with composite resin because this material has the ability to reduce microleakage and also has satisfactory mechanical properties.

It was concluded that none of the materials were able to prevent microleakage in all specimens. Composite resin alone or combined with coltosol and glass ionomer associated with coltosol resulted in less microleakage than the glass ionomer used alone.

\section{Acknowledgements}

The authors deny any financial affiliations related to this study or its sponsors. teeth: part I - time periods. J Endod 1987; 13:56-9.

2. Zaia AA, Nakagawa R, De Quadros I, Gomes BP, Ferraz CC, Teixeira FB, et al. An in vitro evaluation of four materials as barriers to coronal microleakage in root-filled teeth. Int Endod J 2002;35:729-34.

3. Heling I, Gorfil C, Slutzky H, Kopolovic K, Zalkind M, Slutzky-Goldberg I. Endodontic failure caused by inadequate restorative procedures: review and treatment recommendations. J Prosthet Dent 2002;87:674-8.

4. Saunders WP, Saunders EM. Coronal leakage as a cause of failure in root canal therapy: a review. Endod Dent Traumatol 1994;10:105-8.

5. Ray HA, Trope M. Periapical status of endodontically treated teeth in relation to the technical quality of the root filling and the coronal restoration. Int Endod J 1995;28:12-8.

6. Roghanizad N, Jones JJ. Evaluation of coronal microleakage after endodontic treatment $J$ Endod 1996;22:471-3.

7. Schwartz RS, Fransman R. Adhesive dentistry and endodontics: materials, clinical strategies and procedures for restoration of access cavities: a review. J Endod 2005;31:151-65.

8. Yamauchi S, Shipper G, Buttke T, Yamauchi M, Trope M. Effect of orifice plugs on periapical inflammation in dogs. J Endod 2006;32:524-6.

9. Madarati A, Rekab MS, Watts DC, Qualtrough A. Time-dependence of coronal seal of temporary materials used in endodontics. Aust Endod J 2008;34:89-93.

10. Laustsen MH, Munksgaard EC, Reit C, Biørndal L. A temporary filling material may cause cusp deflection, infractions and fractures in endodontically treated teeth. Int Endod J 2005;38:653-7. 
11. Santos J, Tiäderhane L, Ferraz C, Zaia A, Alves M, De Goes M, et al. Long-term sealing ability of resin-based root canal fillings. Int Endod J 2010;43:455-60.

12. Fathi B, Bahcall J, Maki JS. An in vitro comparison of bacterial leakage of three common restorative materials used as an intracoronal barrier. J Endod 2007;33:872-4.

13. Shipper G, Teixeira FB, Arnold RR, Trope M. Periapical inflammation after coronal microbial inoculation of dog roots filled with gutta-percha or Resilon. J Endod 2005;31:91-6.

14. Cecchin D, Almeida JF, Gomes BP, Zaia AA, Ferraz CC. Effect of chlorhexidine and ethanol on the durability of the adhesion of the fiber post relined with resin. J Endod $2011 ; 37: 678-83$.

15. Cecchin D, Souza M, Carlini-Junior B, Barbizam JVB. Bond strength of Resilon/Epiphany compared with Gutta-percha and sealers Sealer 26 and Endo Fill. Aust Endod J 2012;38:21-5.

16. Teixeira FB, Teixeira ECN, Thompson JY, Trope M. Fracture resistance of endodontically treated roots using a new type of resin filling material. J Am Dent Assoc 2005; 135:646-52.

17. Jenkins S, Kulild J, Williams K, Lyons W, Lee C. Sealing ability of three materials in the orifice of root canal systems obturated with gutta-percha. J Endod 2005;32:225-7.

18. Uranga A, Blum JY, Esber S, Parahy E, Prado C. A comparative study of four coronal obturation materials in endodontic treatment. J Endod 1999;25:178-80.

19. Leonard JE, Gutmann JL, Guo IY. Apical and coronal seal of roots obturated with a dentine bonding agent and resin. Int Endod J 1996;29:76-83.

20. Howdle MD, Fox K, Youngson CC. An in vitro study of coronal microleakage around bonded amalgam coronal-radicular cores in endodontically treated molar teeth. Quintessence Int 2002;33:22-9

21. Hernandez R, Bader S, Boston D, Trope M. Resistance to fracture of endodontically treated premolars restored with new generation dentine bonding systems. Int Endod J 1994;27:281-4.

22. Pashley DH, Tay FR, Imazato S. How to increase the durability of resin-dentin bonds. Compend Contin Educ Dent 2011 ; 32:60-4.

23. Deliperi S, Bardwell DN, Wegley C. Restoration interface microleakage using one total-etch and three self-etch adhesives. Oper Dent 2007;32:179-84.

24. Goerig AC, Mueninghoff LA. Management of the endodontically treated tooth. Part II: Technique. J Prost Dent 1983;49:491-7.

25. Hosoya N, Cox CF, Arai T, Nakamura J. The walking bleach procedure: an in vitro study to measure microleakage of five temporary sealing agents. J Endod 2000;26:716-8. 